\title{
Stepwise Algorithmic Approach to Endoscopic Removal of Biliary Partially Covered and Uncovered Self-Expanding Metal Stents 元
}

\author{
Deepanshu Jain, Assaf Stein and Muhammad K. Hasan \\ Center for Interventional Endoscopy, Advent Health, Orlando, FL, USA
}

Self-expanding metal stents play a crucial role in the management of patients with biliary obstruction. Endoscopic extraction of uncovered metal stents (UCMSs) and partially covered metal stents (PCMSs) could be challenging because of tissue ingrowth. No standardized technique can guarantee universal success. We present our technique and experience of endoscopic extraction of biliary stents in two patients with a UCMS and three patients with a PCMS. Three of the five patients had a previous failed attempt of stent extraction at an outside hospital. Overall, our composite success rate was $80 \%(4 / 5)$. The individual success rate was $100 \%$ (3/3) for PCMSs and 50\% (1/2) for UCMSs. The stent-in-stent technique, in which a fully covered metal stent is placed through an existing UCMS/PCMS, was used in $60 \%(3 / 5)$ of the cases, with a success rate of $66.7 \%(2 / 3)$. We share our algorithmic approach to each case, with detailed emphasis on the technical aspects of the procedure. Clin Endosc 2021;54:608-612

Key Words: Biliary partially covered metal stent; Biliary uncovered metal stent; Endoscopic removal

\section{INTRODUCTION}

Biliary self-expanding metal stents (SEMSs) were first introduced in the late 1980s in the United States. SEMSs were initially marketed as uncovered mesh stents, which maintained longer patency than fixed-size plastic stents. Historically, uncovered metal stents (UCMSs) have been solely used for palliation to relieve biliary obstruction secondary to unresectable malignant pancreatic and biliary tract tumors. Because the stent is uncovered, significant tissue ingrowth occurs with time, which prevents stent migration; however, when the stent needs to be removed for obstruction or any other reason, it becomes a major barrier to a safe endoscopic extraction. Currently, three main subtypes of SEMSs are available: UCMSs,

\footnotetext{
Received: July 14, 2020 Revised: July 25, 2020

Accepted: July 27, 2020

Correspondence: Deepanshu Jain

Center for Interventional Endoscopy, Advent Health, 601E Rollins Street, Orlando, FL 32807, USA

Tel: +1-215-715-5844, Fax: +1-407-609-3355, E-mail: deepanshu.jain.25@gmail. com

ORCID: https://orcid.org/0000-0002-0678-3515
}

(c) This is an Open Access article distributed under the terms of the Creative Commons Attribution Non-Commercial License (http://creativecommons.org/ licenses/by-nc/3.0) which permits unrestricted non-commercial use, distribution, and reproduction in any medium, provided the original work is properly cited. partially covered metal stents (PCMSs), and fully covered metal stents (FCMSs). As the stent becomes more covered, the risk of spontaneous migration increases; however, at the same time, it also becomes more amenable to endoscopic extraction, thus expanding its use for benign indications such as refractory biliary strictures and post-liver transplant anastomotic strictures. ${ }^{1}$ UCMSs should be considered for palliation of malignant strictures only, and their placement for benign biliary strictures is strongly discouraged. ${ }^{1}$

Traditionally, the success rate of endoscopic extraction of UCMSs has remained dismal compared with that of FCMSs when routine accessories such as rat-toothed forceps and snares are used. ${ }^{2,3}$ Although the length of the stent, design of the stent (interlace versus zigzag), and indication for the procedure are believed to play a role, they have not shown any statistically significant impact on the success of SEMS removal. ${ }^{2}$ No consensus exists on the time interval from stent insertion to stent removal as a potential variable, with evidence being bi-directional. ${ }^{2,4}$ The only consistent determining factor across different studies has been the presence or absence of stent covering. ${ }^{2,3}$ Consequently, considerable emphasis has been placed on selecting the appropriate subtype of SEMSs depending on the indication. Although rare, scenarios still arise in current practice when removal of a UCMS or PCMS is desired. Novel 
methods such as the covered-stent-in-uncovered-stent technique, initially described for esophageal stent removal, have been successfully extrapolated to biliary SEMSs; however, the experience remains limited. ${ }^{5-7}$

In this article, we describe our experience (along with videos), with emphasis on the technique for endoscopic extraction, of difficult to remove PCMSs and UCMSs from the extrahepatic biliary tree.

\section{CASE REPORTS}

Over a span of 12 months (2019-2020), five cases of endoscopic extraction of biliary PCMSs (3/5) and UCMSs (2/5) were encountered.

\section{Demographics}

The cohort included four women and one man. The average age was 75.4 years (range, $61-82$ years).

\section{Etiology}

All patients had initially presented with symptoms and signs of biliary obstruction, which had prompted the placement of a PCMS or a UCMS. A UCMS had been placed for palliation in two patients, one with a confirmed malignancy (ampulla adenocarcinoma) and the other with a presumed malignant etiology (gallbladder cancer, later found to be benign on post-cholecystectomy pathology). A PCMS was placed in three patients with main-duct intraductal papillary mucinous neoplasm, anomalous pancreaticobiliary junction with choledochocele, and choledocholithiasis.

\section{Clinical presentation}

Three patients had presented with cholangitis and the other two patients were planned for elective stent removal.

\section{First procedure}

Of the five patients, three initially presented at an outside hospital and underwent a first attempt of endoscopic extraction at the respective hospitals; however, stent extraction failed in all three cases. All three patients were consequently transferred to our center. One of the three patients underwent placement of an FCMS through the existing UCMS and a percutaneous transhepatic drain in the setting of cholangitis before transfer. The remaining two of the five patients presented to our center for an index procedure, and both of them underwent placement of an FCMS via an existing UCMS/ PCMS and were scheduled for repeat endoscopic retrograde cholangiopancreatography (ERCP) in 6 weeks for an attempt at stent extraction.

\section{Second procedure}

Two patients with an FCMS within a UCMS (as placed in the prior procedure) underwent a stent extraction attempt using rat-toothed and alligator forceps, with success in one and failure in other. Of the three patients with a PCMS, one had an FCMS placed through the existing PCMS in the prior procedure. Successful removal of stents was achieved in all three patients with the use of rat-toothed and alligator forceps. In addition, one of the patients (PCMS alone) required balloon dilation of the distal part of the stent to aid the extraction.

The details of each case with specific interventions and outcomes are summarized in Table 1.

\section{Technique}

Our approach is described below in a stepwise manner (Fig. $1)$ :

The first step remains sweeping the lumen of the PCMS or UCMS in its entire length across the extrahepatic biliary tree using a balloon catheter with appropriate size. Beyond debris removal, it improves visualization for the assessment of the extent and severity of tissue ingrowth and allows the stent mesh (of the uncovered segment) to more easily expand and collapse when traction is applied at the time of stent removal.

If the tissue ingrowth is limited in extent (PCMS) and severity, a direct attempt at stent removal using rat-toothed or alligator forceps is a reasonable first step (Supplementary Video 1).

If the tissue ingrowth is extensive and/or across the entire length of the stent (UCMS), the stent-in-stent technique should be considered. Ideally, a FCMS $2 \mathrm{~cm}$ longer and having the same or larger diameter than the existing stent (as safely possible) should be selected. The deployment of this stent should be accurate in terms of its position, allowing it to bridge the entire existing UCMS/PCMS and avoiding bifurcation. Repeat ERCP should thereafter be scheduled in 4-6 weeks.

To grab the stent, any of the following accessories can be used: rat-toothed, alligator, or raptor grasper. It is important to grab at least three strands of the stent mesh (one diamond) to allow an adequate grasp and the application of force (Supplementary Video 2). Moreover, if there is a preexisting FCMS within a UCMS/PCMS, then it is important to grasp both stents together, applying the same principles.

Once the stent/s has/have been adequately grasped, the grasping forceps should be tightly pulled followed by slow withdrawal of the scope in a controlled manner while maintaining a constant pull (usually, a very significant pull force is required). Simultaneously, the position of the scope and stent is tracked under fluoroscopy with the intent of not pulling the scope beyond the esophagogastric junction, avoiding iatrogenic complication (Supplementary Video 2). 
Table 1. Descriptive Summary of the Demographics, Etiology, Clinical Presentation, Interventions, and Outcomes for Each Case

\begin{tabular}{|c|c|c|c|c|c|c|c|c|c|c|}
\hline Age & $\begin{array}{l}\text { Gen- } \\
\text { der }\end{array}$ & Etiology & $\begin{array}{c}\text { Type of } \\
\text { stent }\end{array}$ & Presentation & $\begin{array}{c}\text { First attempt at } \\
\text { stent removal }\end{array}$ & $\begin{array}{l}\text { Out- } \\
\text { come }\end{array}$ & Intervention & $\begin{array}{l}\text { Second } \\
\text { attempt } \\
\text { at stent } \\
\text { removal }\end{array}$ & Accessories & Outcome \\
\hline 82 & $\mathrm{~F}$ & $\begin{array}{l}\text { Biliary obstruc- } \\
\text { tion- } \\
\text { 1. Ampullary } \\
\text { adenocarci- } \\
\text { noma }\end{array}$ & UCMS & Cholangitis & $\begin{array}{l}\text { Yes (outside } \\
\text { hospital) }\end{array}$ & Failure & $\begin{array}{l}\text { 1. FCMS placed } \\
\text { through } \\
\text { pre-existing } \\
\text { UCMS } \\
\text { 2. PTC drain } \\
\text { placement } \\
\text { 3. Antibiotics } \\
\text { 4. Referral to } \\
\text { tertiary center }\end{array}$ & Yes & $\begin{array}{l}\text { 1. Rat toothed } \\
\text { forceps } \\
\text { 2. Alligator } \\
\text { forceps }\end{array}$ & $\begin{array}{l}\text { Success } \\
\text { (both } \\
\text { stents re- } \\
\text { moved) }\end{array}$ \\
\hline
\end{tabular}

\begin{tabular}{|c|c|c|c|c|c|c|c|c|c|c|}
\hline 95 & $\mathrm{~F}$ & $\begin{array}{l}\text { Biliary obstruc- } \\
\text { tion- } \\
\text { 1. Main duct } \\
\text { IPMN }\end{array}$ & PCMS & Cholangitis & $\begin{array}{l}\text { Yes (outside } \\
\text { hospital) }\end{array}$ & Failure & $\begin{array}{l}\text { 1. Antibiotics } \\
\text { 2. Referral to } \\
\text { tertiary center }\end{array}$ & Yes & $\begin{array}{l}\text { 1. Raptor } \\
\text { grasper } \\
\text { 2. Rat toothed } \\
\text { forceps }\end{array}$ & Success \\
\hline 70 & $\mathrm{~F}$ & $\begin{array}{l}\text { Biliary obstruc- } \\
\text { tion- } \\
\text { 1. Anomalous } \\
\text { pancreati- } \\
\text { co-biliary } \\
\text { junction } \\
\text { 2. Choledocho- } \\
\text { cele }\end{array}$ & PCMS & Cholangitis & No & N/A & $\begin{array}{l}\text { 1. FCMS placed } \\
\text { through } \\
\text { pre-existing } \\
\text { PCMS } \\
\text { 2. Antibiotics } \\
\text { 3. Schedule } \\
\text { repeat ERCP } \\
\text { in } 6 \text { wks }\end{array}$ & Yes & $\begin{array}{l}\text { 1. Raptor } \\
\text { grasper } \\
\text { 2. Rat toothed } \\
\text { forceps }\end{array}$ & $\begin{array}{l}\text { Success } \\
\text { (both } \\
\text { stents re- } \\
\text { moved) }\end{array}$ \\
\hline 61 & M & $\begin{array}{l}\text { Biliary obstruc- } \\
\text { tion- } \\
\text { 1. Choledocholi- } \\
\text { thiasis }\end{array}$ & PCMS & $\begin{array}{c}\text { Scheduled } \\
\text { stent removal }\end{array}$ & $\begin{array}{l}\text { Yes (outside } \\
\text { hospital) }\end{array}$ & Failure & $\begin{array}{l}\text { 1. Referral to } \\
\text { tertiary center }\end{array}$ & Yes & $\begin{array}{l}\text { 1. Balloon } \\
\text { dilation } \\
\text { (distal part } \\
\text { of stent) } \\
\text { 2. Rat toothed } \\
\text { forceps } \\
\text { 3. Alligator } \\
\text { forceps }\end{array}$ & Success \\
\hline 69 & $\mathrm{~F}$ & $\begin{array}{l}\text { Biliary obstruc- } \\
\text { tion- } \\
\text { 1. Gallbladder } \\
\text { cancer } \\
\text { (post chole- } \\
\text { cystectomy, } \\
\text { pathology } \\
\text { negative for } \\
\text { cancer) }\end{array}$ & UCMS & $\begin{array}{c}\text { Scheduled } \\
\text { stent removal }\end{array}$ & No & N/A & $\begin{array}{l}\text { 1. FCMS placed } \\
\text { through } \\
\text { pre-existing } \\
\text { UCMS } \\
\text { 2. Schedule } \\
\text { repeat ERCP } \\
\text { in } 6 \text { wks }\end{array}$ & Yes & $\begin{array}{l}\text { 1. Raptor } \\
\text { grasper } \\
\text { 2. Rat toothed } \\
\text { forceps } \\
\text { 3. Alligator } \\
\text { forceps } \\
\text { 4. Snare }\end{array}$ & 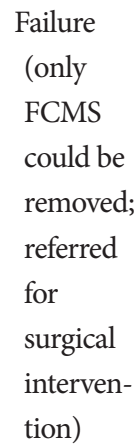 \\
\hline
\end{tabular}

ERCP, endoscopic retrograde cholangiopancreatography; FCMS, fully covered metal stent; IPMN, intraductal papillary mucinous neoplasm; N/A, not applicable; PCMS, partially covered metal stent; PTC, percutaneous transhepatic cholangiogram; UCMS, uncovered metal stent. 


\begin{tabular}{|c|c|c|c|}
\hline Step: 1 & \multicolumn{3}{|c|}{ Cannulation through the stent followed by balloon sweep } \\
\hline & \multicolumn{3}{|c|}{$\nabla$} \\
\hline Step: 2 & \multicolumn{3}{|c|}{ Assess for proximal migration } \\
\hline & Yes & & \multirow{3}{*}{ No } \\
\hline & $V$ & & \\
\hline & $\begin{array}{l}\text { Balloon dilation of distal bile duct up } \\
\text { to the size of stent }\end{array}$ & & \\
\hline & \multicolumn{3}{|c|}{$\nabla$} \\
\hline Step: 3 & \multicolumn{3}{|c|}{ Characterize stent: type, length, diameter, extent of tissue in-growth } \\
\hline & $\begin{array}{l}\text { 1. PCMS } \\
\text { 2. Short in length } \\
\text { 3. Minimal tissue ingrowth }\end{array}$ & & $\begin{array}{l}\text { 1. UCMS } \\
\text { 2. Long in length } \\
\text { 3. Significant tissue ingrowth }\end{array}$ \\
\hline & $\downarrow$ & & \\
\hline & $\begin{array}{l}\text { Direct attempt at stent removal } \\
\text { using rat tooth/ alligator/raptor } \\
\text { forceps }+ \text { /- balloon dilation within } \\
\text { stent }\end{array}$ & $\stackrel{\text { Failure }}{\longrightarrow}$ & $\begin{array}{l}\text { Consider stent in stent technique and plan } \\
\text { repeat ERCP in } 4-6 \text { weeks to attempt } \\
\text { removing both stents using rat tooth/ } \\
\text { alligator/raptor forceps }\end{array}$ \\
\hline
\end{tabular}

Fig. 1. Algorithmic approach to endoscopic removal of uncovered and partially covered metal stents (PCMSs). ERCP, endoscopic retrograde cholangiopancreatography; UCMS, uncovered metal stent.

If the stent/s has/have been only partially pulled out, the above steps need to be sequentially repeated with the forceps grasping the more proximal visible part of the stent at the ampulla at each attempt (Supplementary Video 2).

Balloon dilation is useful in two scenarios: (1) When the stent has migrated proximally and the diameter of the distal bile duct is smaller than that of the stent itself, the distal bile duct needs to be dilated up to the size of the stent. (2) When tissue ingrowth is mild, balloon dilation may help push the tissue out of the stent mesh, allowing easier extraction (Supplementary Video 2).

\section{DISCUSSION}

In current practice, SEMSs play a crucial role in the management of biliary obstruction, especially for palliation in cancer patients who are not surgical candidates and for benign refractory strictures. ${ }^{1}$ Depending on the extent of covering, three subtypes of SEMSs are commercially available: FCMS, PCMS, and UCMS. The more uncovered the stent is, the greater is the amount of tissue ingrowth that develops over time, which leads to less risk of migration but greater difficulty of stent removal, if later attempted. Infrequently, patients with a UCMS or PCMS who have either outlived their life expectancy or were lost to follow-up or were initially intervened on the basis of an incorrect presumptive diagnosis return for stent extraction. The endoscopic extraction of UCMSs and PCMSs could be very challenging, and no standard technique can guarantee universal success.

This is one of those areas in endoscopy in which every individual case is best dealt with a specific tailored plan. We here share our experience of two cases with a UCMS and three cases with a PCMS. Three of the five cases had a failed attempt of stent extraction at an outside hospital. Overall, our composite success rate was $80 \%(4 / 5)$. The individual success rate was $100 \%(3 / 3)$ for PCMSs and 50\% (1/2) for UCMSs. The stent-in-stent technique in which an FCMS is placed through the existing UCMS/PCMS was used in 60\% (3/5) of the cases, with a success rate of $66.7 \%(2 / 3)$. One failed removal occurred in a patient with a UCMS. The major reason for failure to extract was the long size of the UCMS, which extended into the left main hepatic duct. We were unable to bridge the proximal part of the UCMS with a fully covered stent owing to the risk of blocking the right main hepatic duct. This patient was eventually referred for surgery. 
In conclusion, one approach may not fit all cases of UCMS and PCMS extraction from the biliary tree. For a successful and safe outcome, we strongly recommend a stepwise approach. It starts with sweeping of the existing stent to remove any biliary sludge and debris, followed by characterizing the existing stent (type, length, and extent and severity of tissue ingrowth) and subsequently choosing the appropriate strategy (as detailed above). Careful application of each technical step of the chosen approach may make the difference between a successful and failed outcome.

\section{Conflicts of Interest}

Muhammad K. Hasan is a consultant for Boston Scientific and Olympus America. The authors have no potential conflicts of interest.

\section{Funding}

None.

Author Contributions

Conceptualization: Deepanshu Jain

Data curation: DJ, Assaf Stein, Muhammad K. Hasan

Formal analysis: DJ

Methodology: DJ

Supervision: $\mathrm{MKH}$

Writing-original draft: DJ, AS

Writing-review\&editing: $\mathrm{MKH}$

\section{ORCID}

Deepanshu Jain:

Assaf Stein:

Muhammad K. Hasan:
Supplementary Materials

Video 1 . Successful endoscopic removal of a biliary partially covered metal stent (https://doi.org/10.5946/ce.2020.189.v001).

Video 2. Successful endoscopic removal of a biliary uncovered metal stent (https://doi.org/10.5946/ce.2020.189.v002).

\section{REFERENCES}

1. Dumonceau JM, Tringali A, Papanikolaou IS, et al. Endoscopic biliary stenting: indications, choice of stents, and results: European Society of Gastrointestinal Endoscopy (ESGE) clinical guideline - updated October 2017. Endoscopy 2018;50:910-930.

2. Familiari P, Bulajic M, Mutignani M, et al. Endoscopic removal of malfunctioning biliary self-expandable metallic stents. Gastrointest Endosc 2005;62:903-910.

3. Shin HP, Kim MH, Jung SW, et al. Endoscopic removal of biliary self-expandable metallic stents: a prospective study. Endoscopy 2006;38:12501255.

4. Ishii K, Itoi T, Sofuni A, et al. Endoscopic removal and trimming of distal self-expandable metallic biliary stents. World J Gastroenterol 2011;17:2652-2657.

5. Arias Dachary FJ, Chioccioli C, Deprez PH. Application of the "covered-stent-in-uncovered-stent" technique for easy and safe removal of embedded biliary uncovered SEMS with tissue ingrowth. Endoscopy 2010;42(Suppl 2):E304-E305.

6. Tan DM, Lillemoe KD, Fogel EL. A new technique for endoscopic removal of uncovered biliary self-expandable metal stents: stent-instent technique with a fully covered biliary stent. Gastrointest Endosc 2012;75:923-925.

7. Hentschel F, Lüth S. [Removal of an uncovered metal stent from the common bile duct six years after implantation in chronic calcifying pancreatitis]. Z Gastroenterol 2020;58:664-671. 